\title{
Our anesthesia experiences with geriatric patients at high risk group undergoing hip surgery under combined psoas compartment-sciatic nerve block
}

\author{
Kalça cerrahisi geçiren yüksek risk grubu yaşlı hastalarda psoas kompartman - \\ siyatik sinir bloğu kombinasyonu ile anestezi deneyimlerimiz
}

\author{
Kasım Tuzcu*, Günhan Gökahmetoğlu, Emin Silay, Halis Canpolat \\ Department of Anesthesiology and Reanimation (Assist. Prof. K. Tuzcu, MD), Mustafa Kemal \\ University School of Medicine, TR-31034 Hatay, Clinic of Anesthesiology and Reanimation (G. \\ Gökahmetoğlu, MD, H. Canpolat, MD), Kayseri Training and Research Hospital, TR-38010 \\ Kayseri, Department of Anesthesiology and Reanimation (Assist. Prof. E. Silay, MD), Sütçü İmam \\ University School of Medicine, TR-46100 Kahramanmaraş
}

\begin{abstract}
Aim. The effect of psoas compartment and sciatic nerve block combination on hemodynamic parameters in high risk geriatric patients with hip fracture surgeries was evaluated. Methods. In this study, high risk old patients who underwent psoas compartment block and sciatic nerve block for hip surgery anesthesia were evaluated retrospectively. In Group 1 there were 14 patients with levobupivacaine and lidocaine combination and in Group 2 there were 10 patients with levobupivacaine and prilocaine combination. In our study we evaluated the heart rate, systolic blood pressure, diastolic blood pressure, mean arterial blood pressure levels and sedation need between groups, between age over and below 85 years and in all patients. Results. There were no statistically significant difference in heart rate and mean arterial blood pressure levels between groups and age groups ( $\mathrm{p}>0.05)$. There were a $6.18 \%$ and $16.52 \%$ decrease in mean arterial blood pressure in Group 1 and 2 respectively. When we evaluated the whole patients there was a $10.06 \%$ decrease in mean arterial blood pressure. Conclusion. We consider that the combination of psoas and sciatic block as an anesthetic method may be a proper option especially in the elderly and high-risk patients who were underwent the hip surgery.
\end{abstract}

Keywords: Psoas compartment block, geriatrics, hip surgery

Özet

Amaç. Kalça kırı̆̆ı cerrahisi geçiren yüksek risk grubu yaşlı hastalarda psoas kompartman bloğu ve siyatik sinir blok kombinasyonunun hemodinamik parametrelere etkisi araştırıldı. Yöntem. Bu çalışmada kalça cerrahisi anestezisi için psoas kompartman bloğu ve siyatik sinir bloğu ikilisi yapılan yüksek risk grubu, yaşlı hastalar retrospektif olarak değerlendirildi. Lokal anestezik olarak levobupivakain ve lidokain kombinasyonu verilen 14 yaşlı hasta Grup 1 olarak, levobupivakain ve prilokain kombinasyonu verilen 10 yaşı ı hasta Grup 2 olarak adlandırıldı. Çalışmamızda hastaların tümünde, gruplar arasında ve 85 yaşın üstünde olanlarla altında olanların kalp atım hızı, ortalama kan basıncı değerleri ve sedasyon ihtiyacı incelendi. Bulgular. Gruplar arasında ve yaş grupları arasında ortalama kan basıncı değerleri ve kalp atım hızları karşılaştırıldığında istatiksel olarak anlamlı bir fark saptanmadı $(\mathrm{p}>0,05)$. Grup 1'de ortalama kan basıncında \%6,18 düşüş olurken Grup 2'de \%16,52 düşüş oldu. Tüm hastalar değerlendirildiğinde ortalama kan basıncında \%10,06 oranında düşüş gözlendi. Sonuç. Kalça cerrahisi uygulanan yaşlı ve yüksek risk grubu hastalarda anestezik yöntem olarak psoas ve siyatik blok kombinasyonunun uygun bir seçenek olabileceğini düşünüyoruz.

Anahtar sözcükler: Psoas kompartman bloğu, geriatri, kalça cerrahisi

Geliş tarihi/Received: January 02, 2013; Kabul tarihi/Accepted: February 14, 2013 


\section{*Corresponding author:}

Dr. Kasım Tuzcu, Anestezi ve Reanimasyon Anabilim Dalı, Mustafa Kemal Üniversitesi Tip Fakültesi, TR-31034 Hatay. E-mail: tuzcu01@gmail.com

\section{Introduction}

Vast majority of the patients undergoing hip surgery are in advanced age groups. Safe anesthesia should be essential in this group of patients due to high prevalence of comorbid diseases [1,2]. Regional anesthesia techniques such as spinal and epidural anesthesia which are frequently used in hip surgery have some advantages over general anesthesia including maintenance of cognitive functions, reduced amounts of intraoperative hemorrhage, decreased risk for postoperative thromboembolism and providing effective postoperative analgesia. However, there are certain disadvantages such as hypotension, bradycardia, urinary retention, development of block in the nonoperated leg and delayed mobilization $[1,3,4]$.

Hemodynamic side effects such as hypotension and bradycardia caused by spinal block are more prominently seen in patients at advanced ages with poor general status [3]. We think that it should be possible to avoid these hemodynamic side effects as well as other adverse effects of neuraxial block by using lumbosacral plexus block as an alternative method in the lower extremity of such patients.

In the present study, it is aimed to retrospectively review high risk geriatric patients underwent anesthesia under combined psoas compartment-sciatic nerve block for hip surgery.

\section{Material and methods}

After approval of Local Ethics committee, medical records of 26 geriatric patients at high risk group with comorbid diseases who underwent combined psoas compartment-sciatic nerve block for the anesthesia of proximal femoral fracture surgery in Kayseri Teaching Hospital between September, 2009 and September, 2010 were retrospectively reviewed (Table 1). All patients and their relatives were informed about the fact that operation is in the high risk group regarding anesthesia and consent was obtained to perform peripheral nerve block from all patients. A routine monitoring approach was used including electrocardiography, arterial blood pressure and peripheral oxygen saturation. The patients were placed in the lateral decubitus position as being operated leg on the top; followed by sterilization. Winnie technique was used for the psoas compartment block, whereas Labat technique for the sciatic nerve block. Intradermal local anesthesia was achieved by using $2 \mathrm{~mL}$ of $2 \%$ prilocaine. A $100 \mathrm{~mm} / 22$ gauge peripheral nerve stimulator needle was inserted perpendicular to skin. The needle was advanced until it contacted to transverse process of L4 vertebra. Then, needle was retracted and directed to caudal direction in order to pass transverse process. The needle was advanced until contractions were seen in quadriceps muscle. Needle position was optimized and considered as adequate when quadriceps contractions were seen at an output level between 0.4 and 0.5 $\mathrm{mA}$. The position of the needle was considered as appropriate, since contractions maintained. To prevent intravascular drug administration, a gentle aspiration was performed at each injection of $5 \mathrm{~mL}$ local anesthetic solution. Subsequently, Labat technique was used with posterior approach for sciatic nerve block at the same position. $2 \mathrm{~mL}$ of $2 \%$ prilocaine was given for local anesthesia. A $50 \mathrm{~mm} / 22$ gauge peripheral nerve stimulator needle was inserted perpendicular to skin. The sciatic nerve was identified by a nerve stimulator (Stimuplex DB Braun, Melsungen, Germany). Needle position was optimized and considered as adequate when plantar flexion was seen at an output level between 0.4 and $0.5 \mathrm{~mA}$. The position of the needle was considered as appropriate, since plantar flexion of foot continued. To prevent intravascular drug administration, a gentle aspiration was done each time after injection of $5 \mathrm{~mL}$ local anesthetic solution. When medical records were reviewed, it was seen that 14 patients received a local anesthetic 
combination of $20 \mathrm{~mL} 0.25 \%$ levobupivacaine plus $10 \mathrm{~mL} 1 \%$ lidocaine $\mathrm{HCl}$ for the psoas compartment block and a combination of $20 \mathrm{~mL} 0.25 \%$ levobupivacaine plus $10 \mathrm{~mL}$ $1 \%$ lidocaine $\mathrm{HCl}$ for the sciatic nerve block. These patients were designated as Group 1. It was also seen that remaining 12 patients received a local anesthetic combination of 20 $\mathrm{mL} 0.25 \%$ levobupivacaine plus $10 \mathrm{~mL} 1 \%$ prilocaine for the psoas compartment block and a combination of $20 \mathrm{~mL} 0.25 \%$ levobupivacaine plus $10 \mathrm{~mL} 1 \%$ prilocaine for the sciatic nerve block. These patients were designated as Group 2. After block was ensured, the sensory level was bilaterally examined by using a pinprick test. The motor block could not be assessed in the operated leg due to the presence of hip fracture. It was failed to achieve block in 2 cases in Group 2, which were then excluded. The surgical team was allowed to initiate the operation after occurrence of sensory block at incision site. Demographic data, heart rate at baseline and at the minutes 5, 10, 15, 30, 45, 60, 75, 90, 105 and 120, systolic blood pressure, diastolic blood pressure, mean arterial blood pressure (MAP), sedation requirement and incidence of contralateral spread were evaluated. Changes in hemodynamic data by time were analyzed for all patients. Values of blood pressure and heart rate were compared between Group 1 and 2 and between patients above and below 85 years of age.

Table 1. Co-morbid disease in all patients.

\begin{tabular}{lrcll}
\hline Co-morbid disease & \multicolumn{2}{c}{ Group 1 $(\mathbf{n = 1 4})$} & \multicolumn{2}{l}{ Group 2 (n=10) } \\
\hline Congestive heart failure & 11 & $(78.5 \%)$ & 7 & $(70 \%)$ \\
Coronary artery disease & 10 & $(71.4 \%)$ & 7 & $70 \%)$ \\
Atrial fibrillation & 3 & $(21.4 \%)$ & 1 & $(10 \%)$ \\
Hypertension & 6 & $(42.8 \%)$ & 7 & $(70 \%)$ \\
Chronic bronchitis & 1 & $(7.1 \%)$ & 3 & $(30 \%)$ \\
Diabetes mellitus & 7 & $(50 \%)$ & 2 & $(20 \%)$ \\
Severe mitral stenosis & 1 & $(7.1 \%)$ & 2 & $(20 \%)$ \\
Severe aortic stenosis & 1 & $(7.1 \%)$ & 1 & $(10 \%)$ \\
Cerebrovascular disease & 2 & $(14.2 \%)$ & 3 & $(30 \%)$ \\
\hline
\end{tabular}

\section{Statistical analyses}

Were performed by using SPSS version 13. Data were analyzed by using ANOVA test in accordance with the single factor (time) and three-factor trial schedule. The results were expressed as average \pm standard error. $\mathrm{P}<0.05$ was considered as significant.

\section{Results}

Table 2 shows the demographic data and operation duration of the patients in both groups. No significant difference was found between groups in terms of age, weight, and duration of operation.

Table 2. Patient characteristics and duration of surgery.

\begin{tabular}{llll}
\hline & Group 1 $(\mathbf{n}=14)$ & Group 2 $(\mathbf{n}=10)$ & Total $(\mathbf{n = 2 4})$ \\
\hline Age $(\mathrm{yr})$ & $80.14 \pm 1.84$ & $79.30 \pm 2.96$ & $79.79 \pm 1.60$ \\
Sex (male/female) & $7 / 7$ & $1 / 9$ & $8 / 16$ \\
Weight $(\mathrm{kg})$ & $66.71 \pm 2.34$ & $71.90 \pm 2.39$ & $68.87 \pm 1.74$ \\
Duration of surgery (min) & $91.07 \pm 5.37$ & $96.00 \pm 7.63$ & $93.12 \pm 4.39$ \\
\hline \multicolumn{4}{l}{ Data are presented as mean \pm SE or number of patients. } \\
\hline
\end{tabular}

No statistically significant difference was detected between the groups when the variations in the systolic and diastolic blood pressure values were compared.

No statistically significant difference was detected between the groups and between age groups when the MAP values were compared (Figure 1). MAP values was decreased by $6.18 \%$ in Group 1, while it was decreased by $16.52 \%$ in Group 2. However, it didn't reach statistical significance. When all patients were considered, mean arterial pressure was decreased by $10.068 \%$. 


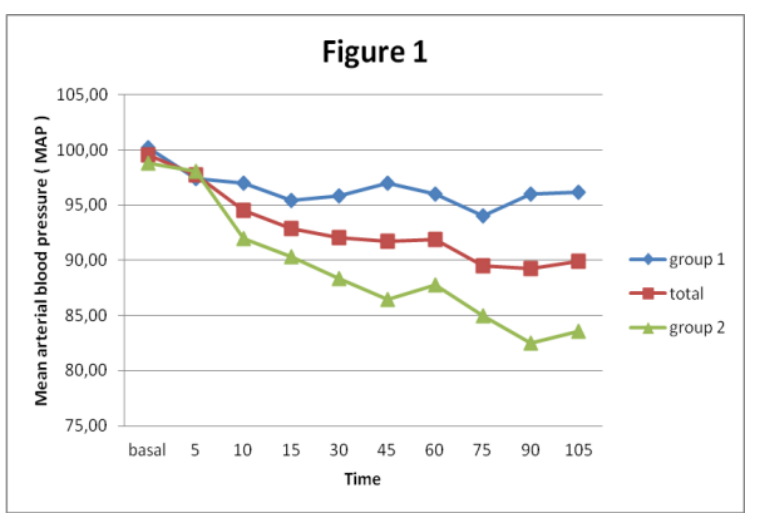

Figure 1. Mean arterial blood pressure values between the groups and all patients. MAP: mmHg, Time: Minute.

No statistically significant difference was detected between the groups and age groups in terms of heart rates (Figure 2).

Sedation was required in 3 patients each in Group 1 and Group 2. One patient in Group 1 had epidural spread.

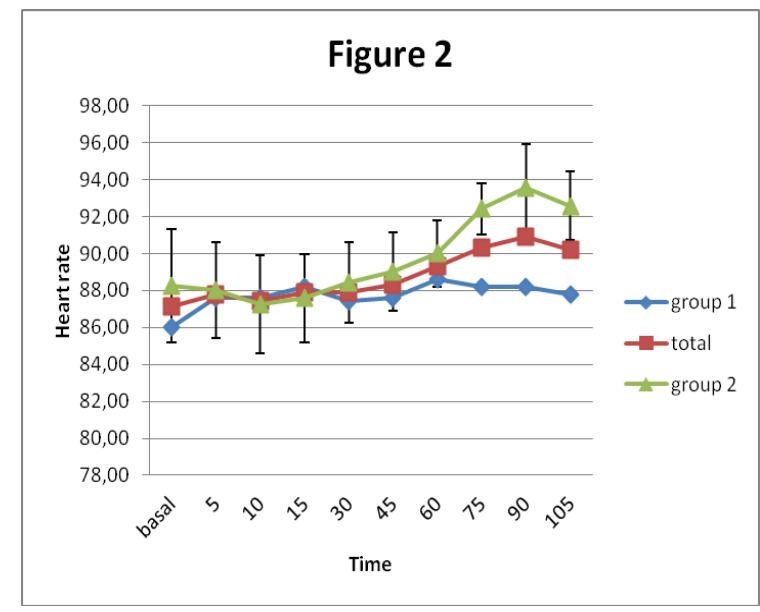

Figure 2. Heart rate values between the groups and all patient. Heart rate: Beats. minute-1, Time: Minute.

\section{Discussion}

The lumbar plexus block, first defined by Winnie, can be used in combination with the sciatic nerve block accompanied by sedation for the anesthesia of hip surgery [5-7]. When compared to central neuraxial blocks, this type of block has some disadvantages such as need for multiple injections, delayed onset of anesthesia, using a high volume of local anesthetic solution and lower success rates [3]. However, autonomic nervous system and blood vessels have a decreased capacity to provide hemodynamic stability in geriatric patients due to some reasons including atherosclerosis, increased systemic vascular resistance and the left ventricular hypertrophy [8]. The combined psoas compartmentsciatic nerve block may be more advantageous than other anesthetic methods in patients undergoing hip surgery who are at high risk in terms of anesthesia and unable to tolerate the hemodynamic instability.

In our study, we evaluated the hemodynamic values in elderly patients at high risk for cardiac complications who received a combined psoas compartment-sciatic nerve blocks for the hip fractures. When all patients were considered, it was observed that MAP was decreased by $\% 10.06$ compared to baseline values. Similar to our results, in a study by 
Leeuw et al. [7] in which hemodynamic changes were investigated in patients received the combined psoas compartment-sciatic nerve block during elective orthopedic surgeries, it was demonstrated that the cardiac index was not affected and the changes in the arterial blood pressure were within the acceptable limits of $<10 \%$.

Eyrolle et al. [9] compared lumbar plexus block with spinal block in the patients underwent surgery involving femur neck. Authors reported that MAP was decreased by $20 \%$ in lumbar plexus block, whereas it was decreased by more than $72 \%$ in spinal anesthesia.

However, in a study by Visme et al. [3], it was reported that the mean baseline arterial blood pressure showed greated decrease in the spinal group than the block group, but it was not statistically significant. Besides, authors also reported that the hypotension period was longer in patients receiving spinal anesthesia; a higher amount of ephedrine was required to stabilize the blood pressure; and blood pressure values showed greater decreases in patients above 85 years of age.

In our study, we compared the hemodynamic values among patients above and below 85 years of age. However, no significant difference was found. Moreover, we also compared the local anesthetic combinations used in this study. When compared to baseline values, mean arterial pressure was decreased by $6.18 \%$ in Group 1 (levobupivacaine plus lidocaine), while it was decreased by $16.52 \%$ in Group 2 (levobupivacaine plus prilocaine), but not reach to statistical significance. We think that the minimal hemodynamic changes observed in our patients may be explained by unilateral sympathetic block within in a limited area achieved by combined psoas compartmentsciatic nerve block.

In a study on femoral neck fractures by Gaillat et al. [10], an adequate anesthesia was achieved in 9 of 11 patients by using the combination of psoas compartment block, sciatic nerve block and sedation and one patient developed evidence of local anesthesia toxicity. In another study on hip surgery, adequate anesthesia was obtained in 10 patients received a combined psoas compartment-sciatic nerve block in addition to propofol sedation, and there was no need for conversion to general anesthesia [1]. In a study by Visme et al. [3], it was failed to achieve adequate anesthesia in 4 of 15 patients; and, of these, incision pain developed in 3 patients, which was prevented with a single dose $250 \mu \mathrm{g}$ alfentanyl, while remaining patient needed sedation. In our study, block failure occurred in 2 cases in group 2, which were then excluded. In Group 1 and 2, 3 patients needed propofol sedation in each.

It is difficult to place patients into spinal flexion position that is needed for the central neuraxial block in patients with fracture because of pain. Spinal calcification and degenerative spinal diseases also enhance this difficulty [11]. The pain is more severe and positioning becomes more difficult in the geriatric patients with hip fracture. In our study, both psoas compartment block and sciatic nerve block were performed readily in lateral decubitus position without requiring excess flexion position. Even though it seems like a simple detail, we consider that this block is more comfortable for both the patient and the clinician in cases where pain renders positioning difficult.

Some authors combined the lumbar block with general anesthesia, where they used this combination in total hip prosthesis and femoral neck fractures. They showed that it decreased the amount of the anesthetic agent used, blood loss and deep venous thrombosis, while improving the postoperative analgesia [1, 12-14]. We used this block in patients of advanced age group with a poor general status in our study. Minimal declines were recorded in the hemodynamic parameters of our patients. The hemodynamic adverse effects which may be potentially seen in general anesthesia and central blocks were not seen.

However, in some animal and human studies, it has been demonstrated that high dose local anesthesia produced a negative inotropic effect in a dose-dependent manner when 
administered via intravascular route [7, 15-17]. Nevertheless, pharmacokinetic studies have indicated the safe use of local anesthetic both as bolus injection and infusion in the psoas compartment block [18-20]. In addition, the local anesthetic toxicity should not be ignored, which has been reported [10]. The toxic dose should be known and local anesthetics should be used at the doses below cardiotoxic dose.

The incidence of epidural spread varies from $3 \%$ and $27 \%$ in the psoas compartment block [2]. In our study, only one patient in Group 1 had epidural spread. The mechanism of epidural block development is related to the local anesthetic dispersion over the proximal segment of the paravertebral area rather than the direct injection through the epidural space. A volume not exceeding $30-40 \mathrm{~mL}$ should be used in order to prevent the epidural spread $[21,22]$. The other potential complications involve total spinal block, intravenous administrations, renal injuries and retroperitoneal hematoma [23-25]. It is recommended to have complete knowledge about anatomy; to perform the local anesthetic injections slowly with frequent aspirations, and to see the contractions clearly in the quadriceps muscle by using a nerve stimulator in order to avoid the complications [21]. In the recent years, since the peripheral structures are more effectively visualized by using sonography and the block is obtained by using lower amounts of local anesthetics; ultrasound-guided peripheral blocks may be safer.

In conclusion, a minimal hemodynamic change were achieved by both psoas compartment and sciatic nerve block in addition to sedation, and was reached a sufficient level of anesthesia in the elderly patients at high risk group of hip surgery. As an anesthetic method, the combination of the psoas and sciatic block seems to be suitable alternative in such these type of patients.

\section{References}

1. Buckenmaier CC 3rd, Xenos JS, Nilsen SM. Lumbar plexus block with perineural catheter and sciatic nerve block for total hip arthroplasty. J Arthroplasty 2002; 17: 499-502.

2. Touray ST, de Leeuw MA, Zuurmond WW, Perez RS. Psoas compartment block for lower extremity surgery: a meta-analysis. Br J Anaesth 2008; 101: 750-60.

3. de Visme V, Picart F, Le Jouan R, Legrand A, Savry C, Morin V. Combined lumbar and sacral plexus block compared with plain bupivacaine spinal anesthesia for hip fractures in the elderly. Reg Anesth Pain Med 2000; 25: 15862.

4. Chudinov A, Berkenstadt H, Salai M, Cahana A, Perel A. Continuous psoas compartment block for anesthesia and perioperative analgesia in patients with hip fractures. Reg Anesth Pain Med 1999; 24: 563-8.

5. Moreno M, Casalia AG. Lumbar plexus anesthesia: psoas compartment block. Techniques in Reg Anesth and Pain Management 2006; 10: 145-9.

6. Mannion S. Psoas compartment block. Continuing Education in Anaesthesia, Critical Care \& Pain 2007; 7: 162-6.

7. de Leeuw MA, Slagt C, Hoeksema M, Zuurmond WW, Perez RS. Hemodynamic changes during a combined psoas compartment-sciatic nerve block for elective orthopedic surgery. Anesth Analg 2011; 112: 719-24.

8. Rooke GA, Robinson BJ. Cardiovascular and autonomic nervous system aging. Problems in Anesthesia 1997; 9: 482-97.

9. Eyrolle L, Zetlaoui P, Belbachir A, Rosencher N, Conseiller C. Regional anaesthesia for femoral neck fracture surgery: comparison of lumbar plexus block and spinal anaesthesia. Br J Anaesth 1998; 80: 383.

10. Gaillat F, Thibault S, Scemama F, Joly F, Paladini M, Auffray J. Bloc lombaire et sciatique posterieur pour fracture du col du femur du sujet age: experience clinique. Cah Anesthesiol 2002; 50: 99-104.

11. Ben-David B, Lee E, Croitoru M. Psoas block for surgical repair of hip fracture: a case report and description of a catheter technique. Anesth Analg 1990; 71: 298301. 
12. Stevens RD, Van Gessel E, Flory N, Fournier R, Gamulin Z. Lumbar plexus block reduces pain and blood loss associated with total hip arthroplasty. Anesthesiology 2000; 93: 115-21.

13. Twyman R, Kirwan T, Fennelly M. Blood loss reduced during hip arthroplasty by lumbar plexus block. J Bone Joint Surg Br 1990; 72: 770-1.

14. Hoek JA, Henny CP, Knipscheer HC, ten Cate H, Nurmohamed MT, ten Cate JW. The effect of different anaesthetic techniques on the incidence of thrombosis following total hip replacement. Thromb Haemost 1991; 65: 122-5.

15. Bruelle P, Lefrant JY, de la Coussaye JE, Peray PA, Desch G, Sassine A, Eledjam JJ. Comparative electrophysiologic and hemodynamic effects of several amide local anesthetic drugs in anesthetized dogs. Anesth Analg 1996; 82: 64856.

16. Lefrant JY, de La Coussaye JE, Ripart J, Muller L, Lalourcey L, Peray PA, Mazoit X, Sassine A, Eledjam JJ. The comparative electrophysiologic and hemodynamic effects of a large dose of ropivacaine and bupivacaine in anesthetized and ventilated piglets. Anesth Analg 2001; 93: 1598-605.

17. Bardsley H, Gristwood R, Baker H, Watson N, Nimmo W. A comparison of the cardiovascular effects of levobupivacaine and rac-bupivacaine following intravenous administration to healthy volunteers. Br J Clin Pharmacol 1998; 46: 245-9.

18. Farny J, Girard M, Drolet P. Posterior approach to the lumbar plexus combined with a sciatic nerve block using lidocaine. Can J Anaesth 1994; 41: 486-91.

19. Simon MA, Gielen MJ, Lagerwerf AJ, Vree TB. Plasma concentrations after high doses of mepivacaine with epinephrine in the combined psoas compartment/sciatic nerve block. Reg Anesth 1990; 15: 256-60.

20. Vanterpool S, Steele SM, Nielsen KC, Tucker M, Klein SM. Combined lumbarplexus and sciatic-nerve blocks: an analysis of plasma ropivacaine concentrations. Reg Anesth Pain Med 2006; 31: 417-21.

21. Cappelleri G, Ghisi D, Fanelli A, Aldegheri G, La Colla L, Albertin A. Posterior psoas vs 3-in-1 approach for lateral femoral cutaneous and obturator nerve block for anterior cruciate ligament repair. Minerva Anestesiol 2009; 75: 568-73.

22. Litz RJ, Vicent O, Wiessner D, Heller AR. Misplacement of a psoas compartment catheter in the subarachnoid space. Reg Anesth Pain Med 2004; 29: 61-4.

23. Pousman RM, Mansoor Z, Sciard D. Total spinal anesthetic after continuous posterior lumbar plexus block. Anesthesiology 2003; 98: 1281-2.

24. Aida S, Takahashi H, Shimoji K. Renal subcapsular hematoma after lumbar plexus block. Anesthesiology 1996; 84: 452-5.

25. Weller RS, Gerancher JC, Crews JC, Wade KL. Extensive retroperitoneal hematoma without neurologic deficit in two patients who underwent lumbar plexus block and were later anticoagulated. Anesthesiology 2003; 98: 581-5. 